\title{
Evaluating the Use of Eggshell Waste Ash in High Strength Concrete
}

\author{
Basim H. Amanah ${ }^{\mathbb{D} *}$, Wasan I. Khalil ${ }^{\mathbb{D}}$ \\ Civil Engineering Department, University of Technology, Baghdad, Iraq. \\ *Corresponding author Email: engbasim82@gmail.com
}

\section{H I G H L I G H T S}

- Reducing the amount of cement in concrete production.

- Positive impact in supporting natural resources' sustainability and depletion of ozone layer by reducing the rate of $\mathrm{CO} 2$ emission.

- Reducing the environment pollution by eggshell wastes.

- Eggshell ash can be used as a partial replacement to cement in concrete.

- Eggshell ash can be used to enhance the durability of concrete.

\section{A R T I C L E I N F O}

Handling editor: Wasan I. Khalil

\section{Keywords:}

Eggshell sash

Sustainable concrete

High strength concrete

\begin{abstract}
A B S T R A C T
This study aims to determine the effect of incorporating eggshell waste as partial compensation from Portland cement material on high-strength concrete mixtures' performance. The properties studied are workability, compressive and flexural strengths, water absorption, dry density, and thermal conductivity. In the same trend, the environmental impact of the replacement mentioned above is evaluated. Four different weight percentages $(0 \%, 5 \%, 10 \%, 15 \%$, and $20 \%)$ of the cement were replaced with eggshells ash. The results indicate that the incorporation of eggshell powder improves the compressive strength and flexural strength by about $14.7 \%$ and $6.5 \%$, respectively, at 28 days age over control concrete mixes at $15 \%$ replacement. The optimum replacement ratio was found to be $15 \%$ based on the strength. Furthermore, the results showed a reduction in water absorption and thermal conductivity as $15 \%$ of eggshell ash was used as a replacement by cement weight with $10.7 \%$ and 10.65 respectively, besides the reduction in the amount of cement used in the mixture. These results are positively reflected in supporting natural resources' sustainability and depleting the ozone layer by reducing the emitted gases.
\end{abstract}

\section{Introduction}

In recent years, growth has increased in all aspects of life, such as in agricultural, industrial, economic, etc., in all countries of the world, which caused a considerable increase in the quantities and types of waste accumulated in these countries. Organic waste is challenging to dispose of by burning or landfilling in the soil. Consequently, they cause air pollution problems through smoke and toxic gases. Therefore, effective solutions are needed to dispose of these wastes that have a harmful environmental impact. Widespread use of concrete leads to environmental problems from greenhouse gas (GHG) emissions resulting from the extraction and manufacturing stages of its components. The cement industry is one of the most emitting steps of gases as a result of burning limestone at high temperatures, which results in about $8 \%$ of the total $\mathrm{CO} 2$ globally, and this number could increase to $8-10 \%$ in coming years $[1,2,3,4]$.

Generally, eggshells must dispose of as waste. When eggshells have been commanded for long periods, they cause skin irritation (allergic) problems and, the smells emitted from them are not desirable in places of litter $[3,5]$. The chemical composition of the eggshell is included calcium carbonate $(\mathrm{CaCO})$, which forms a rate of up to $94 \%$ and, the remaining $6 \%$ includes iron, aluminum, zinc, silica acid, sodium, and phosphorous [6]. In general, this shell consists of multiple layers that are mutually growing of calcium carbonate. Countries with a high production of eggs suffer from the problem of getting cleared of the eggshells, so they resort to landfill operations annually [3].

In general, Iraq suffers the biggest challenges in solid waste management and recycling rate. Although poultry production is extended, eggshell waste is disposed of in large quantities in landfills by burning it, causing harmful gases emitted into the air.

A great majority of previous studies demonstrated the usage of eggshell waste as a partial replacement by the weight of Portland cement with a particle size of 90 microns [7, 8]. Moreover, other studies investigating eggshell powder with $75 \mu \mathrm{m}$ 
size as a partial replacement by weight of cement $[9,10]$ and bigger particles of $2.36 \mathrm{~mm}$ have also been tried with a similar effect. The use of eggshell powder with a fineness less than $250 \mathrm{~nm}$ as a partial replacement of cement in concrete mixtures, not yet been done to know the extent of the effect of what will occur when the fineness is increased. The size applied is smaller than the particle size of fly ash; common pozzolanic materials with grain size are about 1-100 microns. Pozzolanic materials with high finesse improved cement materials $[11,12,13]$; a significant improvement in durability of concrete by filling the micro pores led to the development of microstructure. When eggshells are treated by heating at high temperatures, CaCO3 can be disintegrated into $\mathrm{CaO}$ and $\mathrm{CO} 2$, as manifested in the following equation $[12,14]$.

$$
\mathrm{CaCO} 3 \rightarrow \mathrm{CaO}+\mathrm{CO} 2
$$

Therefore, it is possible to use the burnt eggshells instead of the natural lime rocks used in cement production, which leads to preserving natural lime and reducing cement use, contributing to the sustainability of natural resources [5, 14].The main objective of this research is to achieve environmental sustainability by getting rid of eggshell waste and using it as a partial substitute for cement in the production of high strength concrete, thus reducing the content of cement used in the concrete mixture. As a result, the amount of $\mathrm{CO} 2$ produced by the cement industry will be reduced, and thus the cost will be reduced.

\section{Experimental program}

\subsection{Materials}

Raw materials introduced were Portland cement (OPC) type I, burnt eggshell powder, fine aggregate (sand), coarse aggregate (gravel), water, besides the super plasticizer (type G and F), which were used to prepare the concrete mixes used in this study.

\subsection{Portland cement (OPC)}

The Portland cement (Type I), with the trademark of AL-Jisr, that produced by Lafarge Company/Iraq was used. The physical and chemical properties results of the cement used conform to the requirements of the Iraqi Standard No. 5 (I.Q.S. No. 5:1984) [15].

\subsection{Eggshell Ash (ESA)}

Eggshell waste as a replacement part of cement materials was used in this investigation. They were collected from the eggshell waste after hatching in Barakat Al Zahra hatchery / Diwaniyah Governorate middle of Iraq; the shells cleaned in normal water and air-dried for five days. The shells then hand-crushed, grounded by grinding using a blasting mill located in the Department of Building Research, and sieved to obtain particles with size less than $0.5 \mu \mathrm{m}$. The eggshell powder was treated by heating it in the electric furnace with a burning program at a rate of $10{ }^{\circ} \mathrm{C}$ for every 10 minutes until the final degree of $750^{\circ} \mathrm{C}$ was reached and lasting at this temperature for one hour. Figure 1 display the particle size distribution of the prepared eggshell ash (ESA) used in this investigation. The chemical and physical properties of ESA are offered in Table 1. The last product of ESA had a particle size of $148.3 \mathrm{n} \mu$, which is less than that for OPC 517.2 n $\mu$. Figures 1 and 2 show the particle size distributions of ESA and OPC respectively.

Table 1: Chemical and physical properties of Portland cement type I and eggshell ash

\begin{tabular}{cccc}
\hline Chemical properties (Oxides group) & Portland Cement Type I (\%) & eggshell ash (\%) \\
\hline Calcium oxide & $\mathrm{CaO}$ & 62.5 & 88.1 \\
Silicon dioxide & $\mathrm{SiO}_{2}$ & 21.4 & 3.1 \\
Iron Oxide & $\mathrm{Fe}_{2} \mathrm{O}_{3}$ & 5.2 & 0.24 \\
Aluminum Oxide & $\mathrm{Al}_{2} \mathrm{O}_{3}$ & 4.6 & 0.21 \\
Magnesium Oxide & $\mathrm{MgO}$ & 3.0 & 1.05 \\
Potassium Oxide & $\mathrm{K}_{2} \mathrm{O}$ & 0.9 & 0.4 \\
Sulfur trioxide & $\mathrm{SO}_{3}$ & 2.77 & 0.33 \\
Others Matter & ---- & 6.57 \\
Loss on Ignition & $\%$ & 1.0 & 1.9 \\
\hline \multicolumn{2}{c}{ Specific gravity } & Physical properties & 2.42 \\
Soundness & \multicolumn{2}{c}{3.15} & -0.08 \\
\hline
\end{tabular}




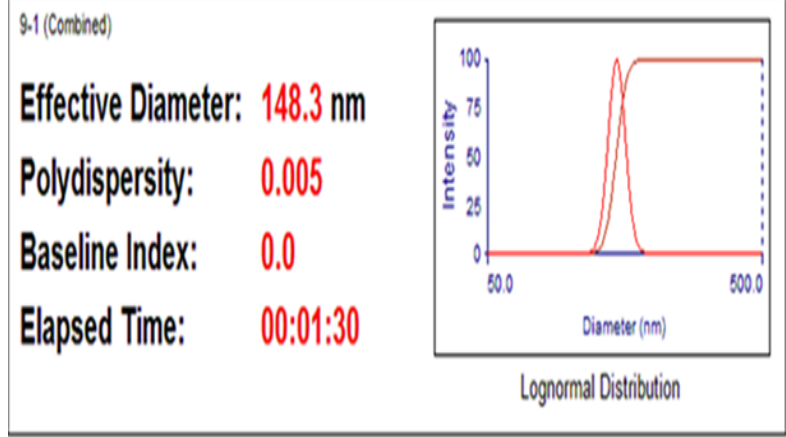

Figure 1: Particle size distribution of prepared eggshells ash

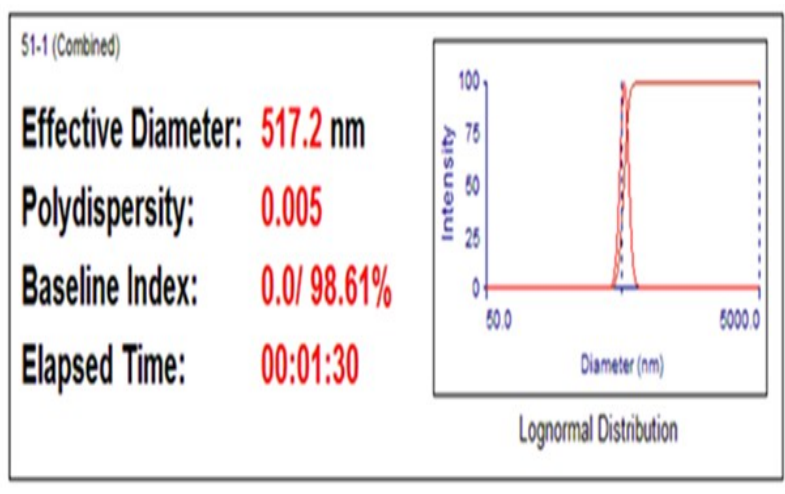

Figure 2: Particle size distribution of Portland cement

\subsection{Sand}

Natural sand with a maximum total size of $4.75 \mathrm{~mm}$ has been applied. The results show that the fine aggregate used is consistent with Iraqi Standard No.45/1984[16].

\subsection{Coarse aggregate}

Locally available natural coarse aggregate brought from the Badra region was used. The maximum particle size of this aggregate is $9.5 \mathrm{~mm}$. Its density is $1663 \mathrm{~kg} / \mathrm{m} 3$, and the laboratory results indicated that it conforms to the Iraqi standard specifications No. 45/1984 [17]. The aggregate used in all the experimental work was saturated with a dry surface condition.

Super plasticizer (HRWRA) Super plasticizer with a trademark of "SikaViscoCrete ${ }^{\circledR}-5930$ " was used. This type of highperformance super plasticizer concrete admixture is free from chlorides and conforms with ASTM C494-14 type G and F [18].

\section{Preparation, casting, and curing of concrete samples}

The concrete samples were made with mix proportion of 1:1.19:1.8 by weight of Portland cement type 1, sand, and gravel. The ESA content was used as a replacement by cement weight at different portions of $(0,5,10,15$, and $20 \%)$ in the concrete mixture. The mixture's ingredients with the ESA were mixed in the dry state in nylon bags to have good homogeneity with cement particles then mixed thoroughly by hand. Potable water was added to the concrete mix with a proportion of 0.27 (water to cement ratio) for all concrete specimens. Table 2 shows the information of the mix quantities for all concrete mixes. Steel cube molds with dimensions of $100 \mathrm{~mm}$ and cylinder molds of $100 \times 200 \mathrm{~mm}$ were used to cast specimens of concrete mixtures. The mixture was left inside the molds for 24 hours and covered with a nylon sheet at $25^{\circ} \mathrm{C}$ inside the laboratory. The molds were removed from the concrete samples, and the concrete specimens were submerged in curing water at a temperature of $21 \pm 2$ till the testing time.

\section{Results and discussion}

\subsection{Workability}

The workability of concrete mixes is illustrated in Table 3. The slump test was measured immediately after mixing according to the ASTM C143 test method [19]. The results show that eggshells ash led to a slight increase in the slump value when increasing the replacement ratio of eggshells ash up to $15 \%$. This is due to the high smoothness particles of the eggshells ash more than the cement granules, which led to the slippage of these particles during the mixing process and facilitated workability. Another reason for the increase in workability is that eggshells ash absorbed mixing water less markedly than Portland cement [20].

Table 2: Details of concrete mixes for various dosages of eggshell ash

\begin{tabular}{ccccc}
$\begin{array}{c}\text { Group } \\
\text { no. }\end{array}$ & Concrete mixes & $\begin{array}{c}\text { Mixes } \\
\text { symbol }\end{array}$ & $\begin{array}{c}\text { Eggshells ash as } \\
\text { weight } \\
\text { replacement to } \\
\text { cement (\%) }\end{array}$ & $\begin{array}{c}\text { Mix proportion for reference mix (M) by } \\
\text { weight }\end{array}$ \\
\hline 1 & Reference & M & 0 & $1: 1.19: 1.8$ by weight (Portland cement: sand: \\
coarse aggregate) cement weight \\
$=525 \mathrm{~kg} / \mathrm{m}^{3}, \mathrm{w} / \mathrm{c}$ ratio $=0.27$, \\
S.P $=1.0 \%$ by weight of cement
\end{tabular}


Table 3: Slump results of concrete mixes

\begin{tabular}{cccc}
\hline Mix symbol & & Eggshells as weight replacement to cement (\%) & Slump (mm) \\
\hline Reference & M & 0 & 110 \\
Concrete mixes contain & M5 & 5 & 115 \\
eggshells ash & M10 & 10 & 120 \\
& M15 & 15 & 125 \\
& M20 & 10 & 105 \\
\hline
\end{tabular}

\subsection{Compressive strength}

Figure 3 shows the influence of incorporating ESA as partial compensation of cement weight in concrete mixes on its compressive strength for ages 7, 28, and 60 days. According to the BS 1881 Part 116 standard, compression strength was calculated for cubic concrete samples of $100 \mathrm{~mm}$ [21]. The results have clearly shown a significant increase in compressive strengths with age. In general, all mixes with ESA show higher performance for all ages than the control mixture. The concrete compressive strength increased to $4.41 \%, 7.35$, and 14.70 over the control mixture when using $5 \%, 10 \%$, and $15 \%$ eggshells ash, respectively, at 28 days. A similar study concluded that mixing eggshell powder as a partial substitution of cement in traditional concrete led to higher compressive strength in the mixture than the reference mixture [14]. One of the basic elements required for the development of strength is calcium oxide $\mathrm{CaO}$ during hydration processes.

For this reason, the oven-dried eggshell powder may be used as a partial substitute for cement weight. Eggshell ash has a large content of $\mathrm{CaO}$, which is expected to provide additional C-S-H gels in concrete microstructure [22, 23]. Moreover, the increase in replacement ratio to more than $15 \%$ of ESA leads to a reduction in compressive strength, which agrees with the results obtained by other researchers [22, 24]. This decrease in compressive strength may be due to reducing the cement content without reducing the water content causes an increase in the water to cement ratio in the mixture; increasing the total porosity which decline the strength at ESA replacement content more than $20 \%$ by weight of cement. Also, the reduction in cement fraction reduces the cement hydration products in hardened concrete.

\subsection{Flexural strength}

Flexural strength at 28-day age was tested according to ASTM C78 [25]. It was demonstrated that the flexural strength is in the same trend as the compressive strength. As illustrated in Figure 4. The flexural strength increases by about 2.41, 3.70, and $6.45 \%$ over the control concrete mix at the substitution ratio of eggshells ash $5 \%, 10 \%$, and $15 \%$ by the cement weight, respectively. Nevertheless, the value of flexural strength has dropped at $20 \%$ replacement. The increased replacement of the eggshell ash may reduce the bond strength between the cement matrix and the aggregate. This decrease in flexural strength may be due to reducing the cement content without reducing the water content causes an increase in the water to cement ratio in the mixture; increasing the total porosity which decline the strength at ESA replacement content more than $20 \%$ by weight of cement. Also, the reduction in cement fraction reduces the cement hydration products in hardened concrete. As a result, the optimum eggshell ash content for the greatest flexural strength was the same for higher compressive strength, $15 \%$. This conclusion agrees with most researchers [26, 27]

\subsection{Water absorption}

ASTM C642 was used to conduct the water absorption [28]. Table4 shows the water absorption ratio for concrete mixtures having eggshells ash. The results demonstrated that the inclusion of ESA reduces water penetration through concrete, the same results was obtained by Dhanalakshmi et al. [29]. This reduction in water absorption is due to the very fine particles of ESA and it's chemically participating in the hydration process under adequate conditions.

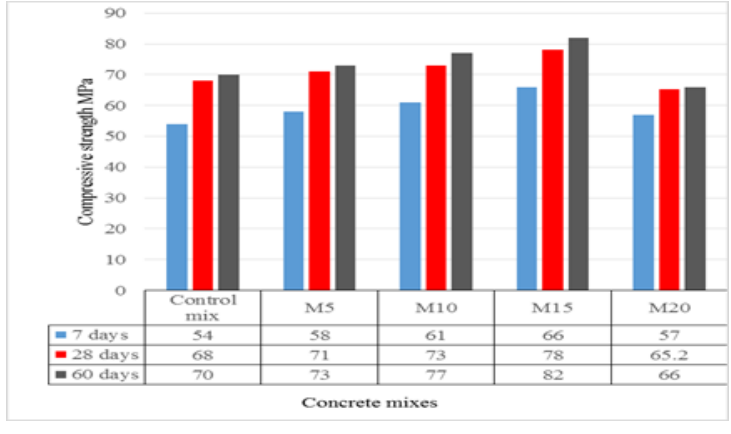

Figure 1: Compressive strength of control concrete mix and mixes containing eggshell ash at different ages.

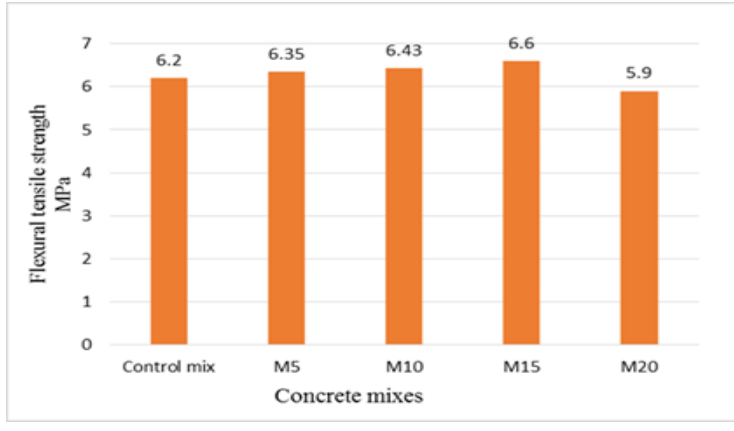

Figure 2: Flexural strength of control concrete mix and mixes containing eggshell powder at 28 days age 


\subsection{Thermal conductivity}

Thermal conductivity test was conducted at the "National Center for Construction Laboratories "as shown in Figure 5 according to ASTM C1113-13[30]. A decrease in the thermal conductivity was observed continuously with increasing levels of eggshell ash. The laboratory results of the control mixture showed a thermal conductivity value of $1.42 \mathrm{~W} / \mathrm{m} . \mathrm{K}$. It was observed that this value decreases with increasing the eggshell ash in concrete mixtures until conduction was measured $1.23 \mathrm{~W}$ $/ \mathrm{m} . \mathrm{K}$ at a content of $20 \%$ eggshell ash. This gives a clear improvement in the thermal insulation of concrete mixes. Moreover, the addition of eggshell ash declined the density of concrete, and this is because the eggshell ash has a specific weight of 2.42, which is less than that of cement (3.15).and this is the reason for the decrease in the density, which is directly proportional to the thermal conductivity. Table 5 shows the variation in thermal conductivity of concrete mixes.

Table 4: Water absorption results of concrete mixes

\begin{tabular}{ccccc}
\hline Mix symbol & & $\begin{array}{c}\text { Eggshells as weight } \\
\text { replacement to cement } \\
\mathbf{( \% )}\end{array}$ & $\begin{array}{c}\text { Water absorption } \\
\text { (\%) }\end{array}$ & $\begin{array}{c}\text { Percentage } \\
\text { Reduction in Water } \\
\text { absorption } \\
(\%)\end{array}$ \\
\hline Reference & M & 0 & 4.11 & -- \\
$\begin{array}{c}\text { Concrete } \\
\text { mixes with }\end{array}$ & M5 & 5 & 3.97 & 3.4 \\
eggshell ash & M10 & 10 & 3.87 & 5.83 \\
& M15 & 15 & 3.67 & 10.70 \\
\hline
\end{tabular}

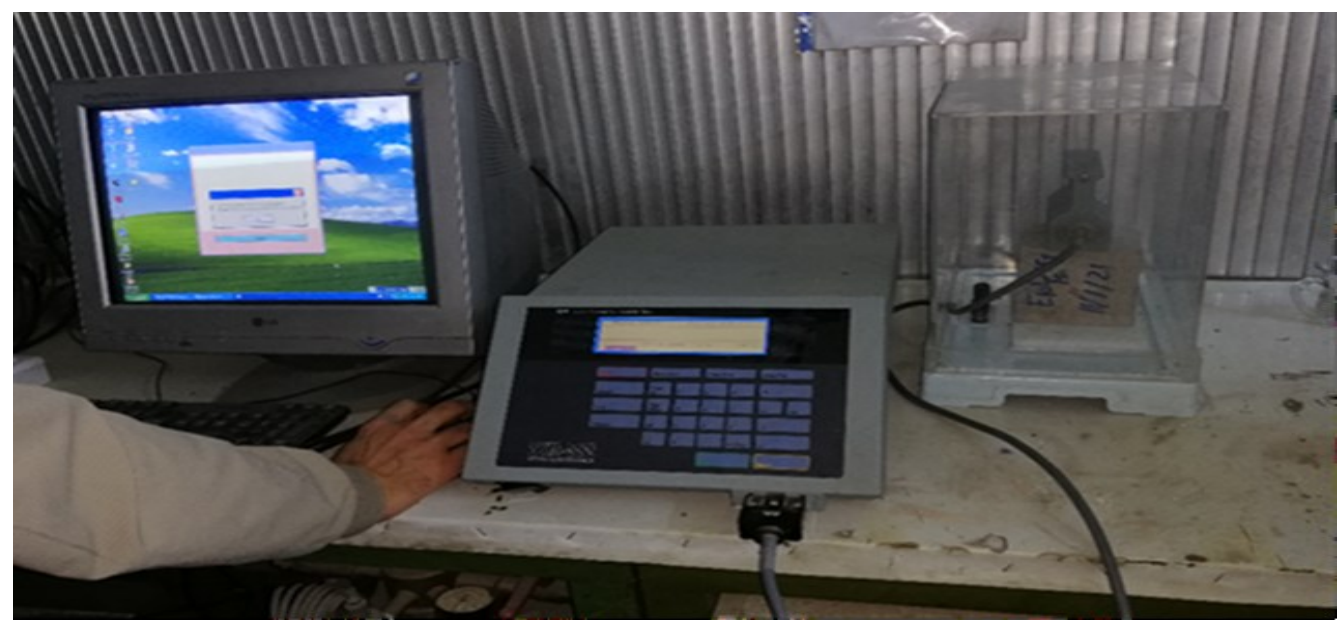

Figure 3: Thermal conductivity test of concrete specimen

Table 5: Oven dry density and thermal conductivity of sustainable concrete containing eggshell ash

\begin{tabular}{cccccc}
\hline Mix symbol & Eggshells as & $\begin{array}{c}\text { Oven dry } \\
\text { weight } \\
\text { replacement } \\
\text { to cement } \\
\mathbf{( \% )}\end{array}$ & $\begin{array}{c}\text { Thermal } \\
\text { consity } \\
\text { conductivity } \\
\text { (W/m.K) }\end{array}$ & $\begin{array}{c}\text { Percentage } \\
\text { reduction in } \\
\text { thermal } \\
\text { conductivity }\end{array}$ \\
\hline Reference & M & 0 & 2238 & 1.42 & --- \\
Concrete & M5 & 5 & 2233 & 1.3 & 8.45 \\
mixes with & M10 & 10 & 2226 & 1.28 & 9.85 \\
eggshells ash & M15 & 15 & 2217 & 1.27 & 10.56 \\
& M20 & 20 & 2208 & 1.23 & 13.38 \\
\hline
\end{tabular}

\section{Conclusion}

This study showed that partial replacement of Portland cement with eggshells ash in high strength concrete mixes led to deductions that can be summarized:

1) The replacement of ESA to high strength concrete mixes gave good properties (workability, compressive strength, flexural strength, water absorption and thermal conductivity) as compared to the concrete mix without ESA. 
2) The eggshell ash properties are nearly similar to the cement in phases of the amount of $\mathrm{CaO}$ in their particles.

3) The influence of ESA on high-strength concrete depends on its substitute level and mixed proportion of concrete.

4) The optimum replacement rate of eggshell ash is $15 \%$, which gave the highest Compressive and flexural strengths and the best performance in concrete.

5) Eggshell ash can be used to enhance the sustainability of concrete materials and reducing the environmental impact of these wastes, which helps preserve the environment.

\section{References}

[1] A. Arrigoni, DK. Panesar, M. Duhamel, T. Opher, S. Saxe , I. D. Posen and H. L. MacLean, "Life cycle greenhouse gas emissions of concrete containing supplementary cementitious materials: Cut-off vs. substitution," Journal of Cleaner Production, Vol. 263, pp. 121465, 2020, doi.org/10.1016/ j.jclepro.2020.121465.

[2] A. Parkash. and R. Singh, "Behaviour of concrete containing egg shell powder as cement replacing material," International Journal of Latest Research In Engineering and Computing (IJLREC), Vol. 5, No. 1, pp. 2347-6540, 2017, [Online]. Available: www.ijlrec.com.

[3] M. M. Than, P. Lawanprasert and S. Jateleela, "Utilization of eggshell powder as excipient in fast and sustained release acetaminophen tablets," Mahidol University Journal of Pharmaceutical Sciences, Sci. 39 (3-4), pp. 32-38, 2012.

[4] W. I. Khalil, Q. J. Frayyeh, and M. F. Ahmed, "Characteristics of eco-friendly metakaolin based geopolymer concrete pavement bricks, " Engineering and Technology Journal, Baghdad, Iraq, Vol. 38, No.11, pp. 1706-1716, 2020, doi.org/10.30684/etj. v38i11A.1699

[5] K. Naidu, C. V. Rao, G. V. Rao, and A. Y. D. T. Akhilesh," Experimental study on M30 grade concrete with partial replacement of cement with egg shell powder," International Journal of Civil Engineering and Technology (IJCIET), India, Vol. 9, No. 5, pp.575-583,2018.

[6] A. M. Abdullah, H. Jaber, and H. A. Al-Kaisy, "Impact strength, flexural modulus and wear rate of PMMA composites reinforced by eggshell powders", Engineering and Technology Journal, Baghdad, Iraq, Vol. 38, No. 7A, pp. 960-966, Jul. 2020, doi.org/10.30684/etj.v38i7A.384

[7] S. Sharma, "Experimental investigation of partial replacement of OPC (43 Grade) cement by egg shell powder for M-35 concrete grade," International Conference on Recent Research and Innovations in Social Science, Humanities, India, pp.19, 2018.

[8] R.A. Al-Safy, "Experimental investigation on properties of cement mortar incorporating eggshell powder," Journal of Engineering and Development, Vol.19, No. 06, 2015.

[9] N. Shiferaw, L. Habte, T. Thenepalliand, J.W. Ahn, "Effect of eggshell powder on the hydration of cement paste," Journal of Materials, Vol.12, pp.2483, 2019, doi:10.3390/ma12152483

[10] M.S. MuhdNorhasri, M.S. Hamidah, and A. MohdFadzil, "Applications of using nano material in concrete: a review," Construction and Building Materials, Vol.133, pp.91-97, 2017. [Online]. Available: http://dx.doi.org/10.1016/j.conbuildmat.2016.12.005

[11] L. Gil, E. Bernat-Maso, and F.J. Canavte, "Changes in properties of cement and lime mortars when incorporating fibers from end of- life tires," Fibers, Licensee MDPI , Basel, Switzerland. 4, 7, pp.1-13, 2016, doi:10.3390/fib4010007

[12] U.N. Okonkwo, I.C. Odiong and E.E. Akpabio, "The effects of eggshell ash on strength properties of cement-stabilized lateritic," International journal of sustainable construction engineering and technology, Vol.3, pp.18-25, 2012.

[13] S. J. Al-Obaidey, "The synergic effect of fly ash and high reactivity attapulgite in ternary blended cement: Fly ash, high reactivity attapulgite, binary blended cement, ternary blended cement", Engineering and Technology Journal, Baghdad, Iraq, Vol. 37, No. 12A, pp. 528-535, Dec. 2019.

[14] A. Yerramala, "Properties of concrete with eggshell powder as cement replacement", The Indian Concrete Journal, pp. 94-102, 2014.

[15] Iraqi specification IQ.S. No 5. (1984), "Portland cement." Central Organization for Standardization and Quality Control, 1984.

[16] Iraqi specification IQ.S. No. 45 (1984), "Natural aggregate used in concrete." Central Organization for Standardization and Quality Control, 1984.

[17] Iraqi specification IQ.S. No. 45 (1984), "Coarse aggregate used in concrete." Central Organization for Standardization and Quality Control, 1984. 
[18] ASTM C494-14, "Standard Specification for Chemical Admixtures for Concrete,", American Society for Testing and Materials, 2014.

[19] ASTM C143M-07, "Standard Test Method for Slump of Hydraulic Cement Concrete", American Society for Testing and Materials, 2007.

[20] Y.Y Tan, S.I. Doh, and S.C. Chin, "Eggshell as a partial cement replacement in concrete development", Magazine of Concrete Research, vol.70, no.13, pp. 662-670, 2018. [Online]. Available: http://dx.doi.org/10.1680/jmacr.17.00003

[21] B.S. 1881 Part 116, "Method for Determination of Compressive Strength of Concrete Cubes", British Standards Institution 1881, 1989.

[22] P. Pliya, and D. Cree, "Limestone derived eggshell powder as a replacement in Portland cement mortar", Construction and Building Materials, vol. 95, pp.1-9, 2015. [Online]. Available: http://dx.doi.org/10.1016/j.conbuildmat.2015.07.103

[23] A.A. Jhatial, W. I. Goh, N. Mohamed, S. Soha and M. T. Lakhiar., "Utilization of palm oil fuel ash and eggshell powder as partial cement replacement-a review," Civil Engineering Journal, Vol.4, No.8, pp. 1977-1984, 2018. [Online]. Available: http://dx.doi.org/10.28991/cej-03091131

[24] M.C. Amaral, F.B. Siqueira, A.Z. Destefani, and J.N.F. Holanda, "Soil-cement bricks incorporated with eggshell waste," Waste and Resource Management, vol.166, pp.137-141, 2013. [Online]. Available: http://dx.doi.org/10.1680/warm.12.00024

[25] ASTM C78-15."Standard Test Method for Flexural Strength of Concrete", American Society for Testing and Materials, 2015.

[26] S. I. Doh, C. and S. Choo, "Eggshell powder: potential filler in concrete," In Malaysia University Conference Engineering Technology, 2014.

[27] F. Adogla, P. P. Yalley, and M. Arkoh, "Improving compressed laterite bricks using powdered eggshells," The International Journal of Engineering and Science, Vol. 5, pp. 65-70, 2016.

[28] ASTM C642-03, "Standard Test Method for Density, Absorption, and Voids in Hardened Concrete", Annual Book of ASTM Standards, American Society for Testing and Materials, Vol. 04-02, 2015.

[29] M. Dhanalakshmi, N. Sowmya and A. Chandrashekar, "A comparative study on egg shell concrete with partial replacement of cement by fly ash ," International Journal of Engineering Research and Technology Vol.4, pp. 1532-1538, 2015.

[30] ASTM C1113/C1113M-09, "Standard Test Method for Thermal Conductivity of Refractories by Hot Wire (Platinum Resistance Thermometer Technique)", Annual Book of ASTM Standards, American Society for Testing and Materials, Vol. 15.01, 2019. 